\title{
GENETIC VARIABIITY AND CHARACTER ASSOCIATION FOR QUALITY TRAITS IN RECOMBINANT INBRED LINES DERIVED FROM INTER SUB-SPECIFIC CROSSES OF RICE (ORYZA SATIVA L.)
}

\author{
AH MadaKemoheKaR*, SS Bornare ANd AS Chavan \\ Department of Plant Breeding and Genetics, College of Agriculture, \\ Jawaharlal Nehru Krishi Vishwa Vidyalaya, Jabalpur-482004 (M.P.), India
}

Key words: Genetic variability, Rice, Path analysis, RIL, Quality trait

\begin{abstract}
The investigation was carried out to study the genetic parameters for quality and nutritional characters in 60 recombinant inbred lines (RIL's) of rice. Analysis of variance revealed significant differences for all the traits. It was observed that grain yield per plant was positively significant associated with seed width, milling per cent, gelatinization temperature, amylose content and kernel breadth before cooking. Kernel length after cooking, seed width, milling per cent, amylose content and gelatinization temperature had positive direct effect on grain yield. Comprehensive examination of result revealed that the recombinant inbred lines tested for high yield in rice viz., RIL-77, 08, 99, 75, 10 and 13 were identified as superior.
\end{abstract}

Rice is the staple food crop of India, providing 43 per cent of caloric requirement for more than 70 per cent Indian population. Majority of the high yielding varieties developed hitherto suffer from poor consumer preference for variable quality. As a consequence, the process of selection for quality traits has become difficult. In situation of this kind, a precise knowledge of the genotypes and extent of correlated response to selection for yield attributes and quality traits would be of great help in planning a systematic breeding programme aiming at either selective or simultaneous improvement of cooking quality in the high yielding background for different consumer regions. Quality of rice may be considered from the view point of size, shape and appearance of grain, milling quality and cooking properties (Khush and Dela Cruz 2000). To achieve goals, the investigation will be conducted with objectives - to identity superior recombinant inbred lines (RIL) based on yield and quality traits. To estimate genetic parameter of variability for yield and quality traits in RILs. To study genotypic and phenotypic association among traits. To estimate path coefficient analysis of traits on seed yield.

The experimental material consists of 60 RILs, derived from inter sub-specific crosses JNPT40-01 $\times$ HMT. JNPT 40-01 a derivative of indica $\times$ japonica and indica rice variety, HMT, are used as parent to develop hybrid which was selected from the conventional Patel 3. All lines were planted in RCBD with three replications on Seed Breeding Farm, Department of Plant Breeding and Genetics, College of Agriculture, J.N.K.V.V., Jabalpur. Each plot comprised of 4 rows of 4 meter length spaced at $20 \mathrm{~cm}$ apart and plant within row at $20 \mathrm{~cm}$. Recommended packages of practices follow to raise a good crop. Genotypic coefficient of variation (GCV) and phenotypic coefficient of variation (PCV) were calculated by the method suggested by Burton (1952). The estimates of PCV and GCV were classified as low, moderate and high according to Sivasubramanian and Madhavamenon (1973).

*Author for correspondence: <anant.madke@gmail.com>. 
Correlation coefficients were calculated for all the character combinations at genotypic and phenotypic levels as per the formula given by Miller et al. (1958). Wright (1921) proposed the original technique but the analysis was carried out by modified method devised by Dewey and Lu (1959). Path coefficients were rated based on the scales given by Lenka and Mishra (1973). The mean range, phenotypic and genotypic coefficient of variation, heritability estimate genetic advance per cent of mean are presented in Table 1.

Table 1. Genetic parameter for yield and its component of RIL's in rice.

\begin{tabular}{|c|c|c|c|c|c|c|c|}
\hline \multirow[t]{2}{*}{ Characters } & \multicolumn{2}{|c|}{ Range } & \multirow[t]{2}{*}{ Mean } & \multirow{2}{*}{$\begin{array}{c}\text { GCV } \\
(\%)\end{array}$} & \multirow{2}{*}{$\begin{array}{c}\text { PCV } \\
(\%) \\
\end{array}$} & \multirow{2}{*}{$\begin{array}{c}\mathrm{h}^{2} \text { (bs) } \\
(\%)\end{array}$} & \multirow{2}{*}{$\begin{array}{l}\text { GA as } \% \\
\text { of mean }\end{array}$} \\
\hline & Min. & Max. & & & & & \\
\hline Seed length (mm) & 5.66 & 7.95 & 6.76 & 12.95 & 13.03 & 98.80 & 26.53 \\
\hline Seed width (mm) & 2.00 & 3.00 & 2.49 & 21.00 & 22.87 & 84.34 & 39.74 \\
\hline Hulling per cent & 74.51 & 84.90 & 79.59 & 4.48 & 4.49 & 99.87 & 9.22 \\
\hline Milling per cent & 56.52 & 85.73 & 77.56 & 15.76 & 15.77 & 99.99 & 32.48 \\
\hline Kernel length before cooking (mm) & 4.05 & 5.42 & 4.76 & 11.87 & 12.01 & 97.70 & 24.16 \\
\hline Kernel breadth before cooking (mm) & 1.74 & 2.40 & 2.08 & 9.48 & 9.64 & 97.03 & 19.24 \\
\hline Kernel length after cooking (mm) & 6.11 & 8.17 & 6.96 & 10.34 & 11.30 & 83.77 & 19.50 \\
\hline Kernel breadth after cooking (mm) & 2.55 & 3.11 & 2.85 & 8.74 & 9.38 & 86.75 & 16.77 \\
\hline Length breadth ratio & 1.79 & 2.87 & 2.32 & 18.22 & 19.37 & 88.43 & 35.29 \\
\hline Length breadth ratio of cooked rice & 2.09 & 3.10 & 2.45 & 12.52 & 12.57 & 99.14 & 25.68 \\
\hline Elongation index & 0.88 & 1.24 & 1.06 & 11.90 & 12.66 & 95.67 & 23.98 \\
\hline Elongation ratio & 1.35 & 1.61 & 1.46 & 10.98 & 10.44 & 94.39 & 24.18 \\
\hline Amylose content (\%) & 13.38 & 22.51 & 18.73 & 69.82 & 69.84 & 99.93 & 8.61 \\
\hline Head rice recovery (\%) & 54.48 & 84.83 & 76.72 & 17.70 & 17.76 & 99.96 & 36.45 \\
\hline Gelatinization temperature $\left({ }^{\circ} \mathrm{C}\right)$ & 56.00 & 79.00 & 72.03 & 19.72 & 19.72 & 100.00 & 40.63 \\
\hline Grain yield & 17.57 & 42.87 & 30.69 & 32.18 & 32.23 & 99.72 & 66.21 \\
\hline
\end{tabular}

Considering the magnitude of phenotypic and genotypic coefficient of variation it was revealed that amylose content, seed width, grain yield/plant and gelatinization temperature had relatively larger amount of genetic variability. In the present investigation, high heritability coupled with high genetic advance were exhibited for characters viz., amylose content, grain yield/plant and gelatinization temperature. Such value indicated predominantly the presence of additive gene action in the expression of these traits and consequently greater chance of improving these traits through simple selection. High heritability coupled with low genetic advance was also observed for seed width, head rice recovery, seed length, elongation index, and length breadth ratio, such value indicate non-additive gene action and influenced by the favorable environment rather than genotypes. These results were in agreement with the finding of Bisne et al. (2009), Tyagi et al. (2004), Sinha et al. (2004), Elayaraja et al. (2004).

The grain yield per plant was positively significant associated with seed width, milling per cent, gelatinization temperature, amylose content, kernel breadth before and after cooking at both genotypic and phenotypic level. These results agree with the findings reported by Sarawgi et al. (1997), Elabd and Abd Allah (2004), Verma and Shrivastava (2004) and Singh et al. (1998).

The path coefficient analysis revealed that, kernel length after cooking, seed width, milling per cent, amylose content and gelatinization temperature had positive direct effect on grain yield per plant and therefore these traits will be given due importance while practicing 
selection aimed to improve grain yield of RIL's in rice. The high positive indirect effect were observed for kernel length after cooking via seed length, length breadth ratio via amylose content was also important. These results agree with the findings reported by Sarawgi et al. (1997), Nandan et al. (2010) and Shanthala et al. (2004). On the basis of above finding the recombinant inbred lines tested for high yield in rice viz., 77, 08, 99, 75, 10 and 13 were identified superior lines with respect to yield and its component characters.

\section{References}

Binse R, Sarawagi AK and. Verulkar SB 2009. Study of heritability, genetic advance and variability for yield contributing character in Rice. Bangladesh J. Agril. Res. 34(2): 175-179.

Burton GW 1952. Quantitative inheritance in grasses. Proc. $6^{\text {th }}$ Int. Grassland Cong. 1: 127-83.

Dewey DR and Lu KH 1959. A correlation and path coefficient analysis of component of crested wheat grass seed production. Agron. J. 51: 515 - 518

Elayaraja K, Prakash M, Saravanan K, Kumar BS and Ganesan J 2004. Studies on variability and heritability in M2 generation of rice (Oryza sativa L.). Research on Crops 5(2/3): 240-242.

Elabd El AB and Abd AA Allah 2004. Genetic behaviour of some grain quality characters in rice (Oryza sativa L.). Egyptian J. Agril. Res. 82 (1): 167-182.

Khush GS and Dela Cruz 2000. Rice grain quality evaluation procedures. Aromatic rices. Singh RK, Singh US, Khush GS (eds). Oxford and IBH publishing Co. Pvt. Ltd. New Delhi, 15-28.

Lenka D and Mishra B 1973. Path coefficient analysis of yield in rice varieties. Ind. J. Agric. Sci. 43 : 376-379.

Miller DA, Williams JC, Robinson HF and Comstock KB 1958. Estimates of genotypic and environmental variances and covariances in upland cotton and their implication in selection. Agron. J. 50: 126-131.

Nandan R, Sweta and Singh SK 2010. Character association and path analysis in Rice (Oryza sativa L.) genotypes. World J. Agri. Sci. 6(2): 201-206.

Sarawgi AK, Rastogi NK and Soni DK 1997. Correlation and Path analysis in rice accessions from Madhya Pradesh. Field Crop Res. 52: 161-167.

Shanthala J 2004. Path coefficient analysis for grain yield with yield components in hybrid rice. Environ. and Ecol. 22(4):734-736.

Singh, SB, Srivastava RH, Giri SP and Yadav LS 1998. Heritability, genetic advance and correlation studies in indigenous rice (Oryza sativa L.) Cultivars of Uttar Pradesh. J. Living World 5: 11-14.

Sinha S.K, Tripathi AK and Bisen UK 2004. Study of genetic variability and correlation co-efficient analysis in midland landraces of rice. Ann. Agril. Res. 25(1): 1-3.

Sivasubramanian J and Madhavamenon P 1973. Genotypic and phenotypic variability in rice. Madras Agric. J. 12: 15-16.

Tyagi, K, Kumar B, Ramesh B and Tomar A 2004. Genetic variability and correlation for some seedlings and mature plant traits in 70 genotypes of rice. Research on crops 5: 60-65.

Verma OP and Srivastava HK 2004. Productive association of quantitative traits in diverse ecotypes of rice (Oryza sativa L.). J. Sustain. Agric. 25(2): 75-91.

Wright S 1921. Correlation and causation. J. Agric. Res. 20: 557-587.

(Manuscript received on 23 December, 2012; revised on 14 November, 2013) 